\title{
THE ONGOING MILITARY CONFLICTS IN SYRIA AND YEMEN: RECENT DEVELOPMENTS, THEIR CONSEQUENCES, AND SCENARIOS
}

The Middle East region has been the world's most turbulent region for decades. Yet the current state of international affairs as well as number of conflicts seems to be unprecedented. As Marc Lynch put it, "the Arab uprisings have galvanized this catalogue of horrors, but all are rooted in the political order shaped by decades of Arab autocracy. The sectarianism, extremism, and social polarization of today's Arab politics were not created by the protestors who took to the streets to demand the overthrow of their regimes. They were created by those regimes" (Lynch, 2016: 254).

The main aim of the article is to analyse in detail roles played by various regional and non-regional state actors in two of the ongoing Middle Eastern conflicts, namely in Syria and in Yemen, in the period between March 2015 and May 2017. ${ }^{1}$ The year 2015 was very significant. That year the Russian military intervention in Syria began and the conflict in Yemen broke out and was internationalized simultaneously. Although such state-oriented approach is very neorealistic, it can be justified in case of the Middle East region as "the state system is the main determinant of the behaviour of its constituent states, its 'anarchy' imposing security-maximizing behaviour on all. These states operate in a particularly anarchic regional system, with border conflicts and irredentism built in at its formation and containing two of the world's most durable conflict zones" (Hinnebusch, 2014: 17).

In both cases there are two levels of analysis. The first is regional and is connected with various actions undertaken by regional powers such as Saudi Arabia, the Islamic Republic of Iran, and Turkey. The second is global and refers to such state actors as the United States, the Russian Federation or the People's Republic of China.

\section{SYRIA: A NEVER-ENDING WAR?}

\section{The Long Shade of Tehran}

There are many misconceptions and misunderstandings related to the Syrian-Iranian political alliance especially in the light of Tehran's support for Bashar al-Assad. In 2016

${ }^{1}$ Roles of non-state actors in the Middle East, especially terrorist organizations, have been analysed in detail in another article of this volume. 
Iran's motivation still stemmed from strategic and pragmatic assumptions rather than sectarian or ideological reasons. The main aim of the Iranian grand strategy is to lead the whole Muslim community in the world, not only Shiites. Kathleen H. Hicks and Melissa G. Dalton emphasize the fact that "while Iran's backing of the Syrian regime is not motivated by sectarianism, there is awareness in Iran that its active intervention, along with Hezbollah's, has fuelled the perception of Iran as primarily a sectarian actor. This perception undermines the benefits Iran might reap through its anti-American and anti-Israeli stances. [...] Concerns have also been expressed about the effects of the Syrian government's brutality and the impact it will have given Iran's support" (Hicks, Dalton, 2017: 14). Tom Cooper also underlines the fact that although Syria and Iran are not natural allies, Iran's support for the Assad regime "is partly related to its need for Syria as an Arab ally against the Sunni Arab states - foremost Saudi Arabia - but especially for Syrian support for the Iranian proxy in Lebanon, the Hezbollah. [...] As usual in such cases, the methods in which the Islamic Revolutionary Guard Corps IRGC became involved more resembled a combined - intelligence and commercial - enterprise than a classic, conventional military intervention" (Cooper, 2015: 48). As long as Assad is in power, Hezbollah will have access to the Eastern Mediterranean. As far as the level of the Iranian military support is concerned, in 2016 the total number of regular forces, the IRGC's soldiers, and non-Iranian forces deployed by Iran was estimated at around 70,000 (Rafizadeh, 2016). According to such estimates, they outnumbered Assad's forces in Syria. Besides, it has to be underlined that death toll among Iran's forces in Syria passed 1,000 in November of the same year (Sharafedin, 2016).

According to Kenneth Katzman, "Russia's intervention in Syria apparently emboldened Iran that its maximum goals in Syria could be achieved, and since late 2016, Iran has apparently continued to pursue that goal in new conflict resolution negotiations brokered by Russia and with Turkey" (Katzman, 2017: 39). The invitation to the Astana process let Iran upgrade its regional position as well as proved that Tehran can play a constructive role in international relations. This way a country widely associated with its nuclear program and power projection in the Middle East appeared to be one of the most influential peace brokers. It is very unlikely that Iran will withdraw its support for Assad as long as he personally guarantees the protection of Iran's geostrategic interests.

\section{The Turkish Involvement}

It would be very hard to deny that, as Joshua W. Walker put it, Turkey's “imperial legacy can serve as both a constraint and an opportunity for a Turkish grand strategy. $[\ldots]$ The prestige associated with playing an active regional role seems to be driving the resurgence in the glorification of imperial memories and the emphasis on recapturing Ottoman thinking on the part of the current government" (Walker, 2012: 31). There is no doubt that the ruling Justice and Development Party and its key ideologists like Ahmet Davutoglu have begun formulating the priorities for the Turkish foreign policy in the framework of so-called Neo-Ottomanism since the very beginning of the AKP rule. As the Turkish authorities perceived the existing states and borders as remnants of the colonial order, especially of the Sykes-Picot Agreement of 1916, the Arab Spring 
provided Ankara with a unique opportunity to modify the existing regional order on its own terms. Bashar al-Assad, a political ally before 2011, suddenly became an enemy of the then Turkish prime minister Recep Tayyip Erdogan. Soon after that Turks began supporting various rebel groups in Syria. And Turkey, along with its allies like Qatar or Saudi Arabia, counted on a military victory and ascension to power of opposition leaders. Yet the Assad regime could rely on a significant support from Iran and Russia what resulted in a stalemate. In such circumstances, the establishment of the Islamic State in 2014 "provided an opportunity for Saudi Arabia, Qatar, and Turkey. All three states held that IS was a problem, but so was the Assad regime in Syria. More importantly, in their views, the two problems were intimately linked" (Baskan, 2016: 132).

The events of 2016 proved, however, that what had seemed achievable in the first years of the conflict was not possible any longer. As Robins put it, "initially, Erdogan assumed that the regime of Bashar al-Assad would simply buckle under internal pressure. This was not an iconoclastic position, as it was shared by many other analysts and governments. [...] It is also likely that Erdogan was increasingly influenced by the sectarian numbers game. This he saw as a reflection of the minoritarian nature of Syria's Alawite regime, with Alawites composing just 11 percent of the Syrian population compared to its 60 percent Sunni Muslim majority" (Robins, 2014: 332). All such assumptions appeared to be fatal miscalculations. In 2016 the situation in Syria posed a far bigger threat to the Turkish national security than at the very beginning of the conflict. Almost all local developments were not in line with Turkish expectations. Russia increased its military presence, Iran sent more IRGC's soldiers and increased its support for various proxies, the Islamic State conducted several terrorist attacks on the Turkish territory, and, last but not least, Kurds in northern Syria got their strength back. Besides, Turkey still had to cope with millions of Syrian refugees. As if all that weren't enough, the United States armed the People's Protection Units - YPG, a Kurdish militia in Syria.

As a result, it became obvious that Turkey finally lost its military influence in Syria. The rebel groups supported by Ankara lost the battle of Aleppo as well as other strategically significant skirmishes with the regime forces. If the Turkish authorities wanted to maintain some political influence in the future, they would have to seek compromise and closer cooperation with key Damascus' allies, namely Russia and Iran. Some scholars suggest that had Turkey intervened militarily in Syria before 2015, it could have toppled the Assad regime. The others, however, claim that such scenario was simply unrealistic. According to Robert Mason, "Turkey could have intervened in Syria where the United States was unwilling or unable to, especially through putting boots on the ground to establish what the government in Ankara called for: safe zones. However, its battle with the PKK and many problems with allies make that increasingly unlikely" (Mason, 2017: 140).

\section{The Arab States of the Persian Gulf: (Un)divided}

At the very beginning the anti-Assad uprising in Syria was not welcomed by the Arab states of the Persian Gulf in general and by Saudi Arabia in particular. Although they got no business defending al-Assad, another sudden regime change in the region could 
have posed a real threat to national security and stability of the other autocratic regimes especially in Saudi Arabia, Bahrain, and the UAE. Later, when this risk was gradually diminishing, the civil war in Syria appeared as a unique opportunity for a regime change in Damascus. And there is no doubt that it was not Syria that was the most important element in this game, but rather Assad's links and support for the Saudis' arch-rival: Iran. As Christopher Phillips put it, "were Assad to fall it would be a blow to Riyadh's regional nemesis, just as it seemed that Tehran was going to be the big beneficiary of the Arab Spring" (Phillips, 2016: 69). Obviously, Tehran has been very concerned with all political developments in Syria and has perceived them as a direct threat to its national security since the very beginning, namely 2011 . For this reason Iranians were and still are determined to provide Assad with both political and military help. If Iran lost its only ally in the Arab world, consequences for its geostrategic position in the Middle East region could be devastating. As F. Gregory Gause described that, "Riyadh has responded to the new Iranian challenge by supporting the opposition to Syrian president Bashar al-Assad, Iran's major Arab state ally" (Gause, 2014: 191). It goes without saying that Donald Trump's victory in the U.S. presidential elections in 2016 provided the Saudi monarchy with new opportunities and freed its hands in Syria. The period during which some Saudi representatives were accused of supporting the so-called Islamic State seems to be over.

At the same time some Arab states, notably Qatar, were accused of supporting rebel groups including radical Islamists in Syria. Undoubtedly, the Qatar's number one priority is to remove the Syrian president from power. At the same time the Qatari monarchy is often accused of jeopardizing regional security. Doha allegedly offered assistance and sent arms to the Army of Conquest - Jaish al-Fatah which contained some groups connected directly to al-Qaeda. By the way, such activities resulted in a regional isolation of Qatar in June 2017.

\section{The Clash of the Titans: the Russian Federation versus the United States}

In the opinion of Karina Fayzullina, "Assad has never been Moscow's best friend. [...] First of all, Russia seeks to secure stability in the region, and secondly to strengthen its positions in world politics on a global level. [...] The overthrow of the regime with the help of international forces will not yield effective results while there is no coherent vision or political programme for the future" (Fayzullina, 2016: 616). Such opinion is supported by other scholars like Bryan B. Gibson who claims that "Russia had shifted the balance of power in the conflict in the regime's favour. In doing so, the Russians opened up room for peace talks" (Gibson, 2017: 20). Yet these talks were to be conducted under conditions laid down by Moscow.

Undoubtedly, the Russian military engagement in Syria in 2015 radically changed the situation on the ground. Moscow's new active attitude towards the conflict resulted in its further internationalization and added a new, global dimension. For instance, Russian military presence forced other actors especially the United States to intensify their efforts in Syria. Moreover, Russia's cooperation with the Iranian troops in Syria encouraged key Assad's rivals at that time, namely Turkey and Saudi Arabia, to in- 
crease support for their local proxies. Such point of view is shared by Charles L. Glaser and Rosemary A. Kelanic who underline the fact that "Russian military intervention in the fall of 2015 to support the Bashar al-Assad government widened the crisis over the Syrian civil war" (Glaser, Kelanic, 2016: 4). Finally, Moscow has invested billions of dollars in the Syrian war so far. No doubt the Russian authorities would like to recover the money as soon as possible.

The U.S.-Russia divergent views on the conflict in Syria as well as ways of its comprehensive resolution seem to be the most significant as far as international relations at global level are concerned. The tensions between Washington D.C. and Moscow transformed a regional conflict into a global one in a political sense. As a result, a lasting settlement without a prior U.S.-Russia accord is no longer possible. In 2016 and 2017 both sides undertook their own diplomatic initiatives to bring the fighting parties to a negotiation table. Yet at the same time both Russia and the United States referred to the use of force in order to achieve their particular goals in Syria. While the Russian air force continued its campaign against opponents of the Assad regime, initiated in 2015, the United States bombed a Syrian airbase, namely al-Shayrat airfield, in response to a chemical weapons attack against civilians in Khan Sheikhoun. U.S. Secretary of State Rex Tillerson stated that day: "It is also clear that this horrific conflict, now in its seventh year, demands a genuine ceasefire and the supporters of the armed combatants in the region need to ensure compliance. We call upon Russia and Iran, yet again, to exercise their influence over the Syrian regime and to guarantee that this sort of horrific attack never happens again. As the self-proclaimed guarantors to the ceasefire negotiated in Astana, Russia and Iran also bear great moral responsibility for these deaths" (Tillerson, 2017).

At the same time the Russian Federation invested a lot of effort in the so-called Astana process, which resulted in an agreement signed by Russia, Iran, and Turkey on May 4, 2017. This event was preceded by long diplomatic talks and intense exchange of notes. It seems that Moscow achieved three goals at the same time. Firstly, it showed the world that Russians can work as middlemen and have significant political influence in the Middle Eastern region. Secondly, visits of various leaders only proved that Russia was coming out of international isolation in which it had found itself after the annexation of Crimea in 2014. Alexey Khlebnikov claims that "the success of the Astana talks will define the outcome for the Syrian war, and Russia's image in general. Through the Astana process, Russia managed to bring together the two main regional actors involved in the conflict on the ground, which has decreased the intensity of fighting in certain areas. If, however, the Astana platform fails to produce tangible results, Moscow risks to lose its credibility, which will make all future Russian initiative more doubtful for the other stakeholders" (Khlebnikov, 2017). And finally, the Russian authorities proved that the new international order can be shaped within the Eurasian rather than the Euroatlantic system. This is a major shift which is in line with the current Russian geopolitical view of the world and which is promoted by some influential scholars like, for instance, Alexander Dugin. The main aim of the Russian-Iranian cooperation is to counterbalance the American influence in the region. Yet one has to emphasize the fact that there is a high level of mutual mistrust between the Russian and Iranian authorities, and therefore their current alliance is of a purely pragmatic nature. 
On the basis of the Astana process, four de-escalation zones were to be created in order to restore peace and order in Syria. Yet a few essential problems and challenges appeared here. Firstly, the agreement was signed by only three parties and by just one permanent member of the United Nations Security Council. Secondly, not all interested sides of the conflict were present there for obvious reasons. Thirdly, as Charles Lister rightly put it, "this latest initiative lacks any enforcement mechanisms, meaning violators will face no consequences. Russia, Iran and the Assad regime are permitted to continue attacks on suspected al-Qaeda-linked groups, which happen to be conveniently present in all four zones. The memorandum spoke of deploying thirdparty observers, but the Assad regime has said it would treat such a move as a hostile act” (Lister, 2017a).

Nevertheless, Russian Foreign Minister Sergei Lavrov tried to guarantee American support for the project during his visit to the United States of 10 May. He talked to U.S. Secretary of State Rex Tillerson in Washington D.C. Besides, the head of Russian diplomacy had also met President Donald Trump who later described their talk as "very, very good." Besides, he was to emphasize the need for a closer bilateral work to end violence in Syria and Ukraine, as well as "floated the prospect of U.S.-Russia cooperation on resolving Middle East conflicts and returned to a campaign theme by emphasizing his desire for better relations with Moscow" (Acosta, Smith-Spark, Gaouette, 2017).

At the very beginning of 2017 everything indicates that the U.S.-Russia rapprochement may be a key to success of peace negotiations in Syria. Nonetheless, Moscow still supports Assad and his forces while Washington is arming Kurdish militias in northern Syria.

\section{The New Player: China and Its Interests in Syria}

The People's Republic of China is known for avoiding any direct interference in internal affairs of other countries. The Chinese authorities tend not to engage in any political disputes or rivalries as long as they do not pose any threats to the Chinese national security or trade interests. The same phenomenon could have been observed when the so-called Arab Spring began. As Jon B. Alterman put it, when the United States welcomed the Arab uprisings, China, "by contrast, viewed them with alarm. Rather than celebrate them, the Chinese government sought to limit domestic reporting on them, fearful of spawning a copycat uprising in China itself. When the results of the Arab revolts of 2011 were far less clear, it looked as if China had a major problem brewing in the Middle East" (Alterman, 2017: 12). At the beginning this observation had been true also in case of the Chinese approach towards the Syrian conflict, yet everything changed in 2016. Although Beijing rarely takes sides in international disputes or conflicts between third parties, it suddenly modified its tactics and began openly supporting Bashar al-Assad. It's a fact that China, along with the Russian Federation, had vetoed the UN Security Council's resolutions condemning policy and actions undertaken by al-Assad long before 2016. Yet at the same time it avoided any clear declarations or judgments what was in line with its foreign policy principles espe- 
cially non-interference in domestic affairs. So, what were the reasons of such a radical change of 2016 ?

According to Michael Clarke and Raffaello Pantucci, "looking to the Syrian context in particular, there are two major reasons for China's apparent decision to begin playing a more forward role in engaging in Syria. One is China's concern at the numbers and links of Uighur militants from its restive province of Xinjiang participating in the Syrian conflict. The other is its desire for geostrategic stability in the Middle East as it seeks to consummate its One Belt, One Road strategy" (Clarke, Pantucci, 2016).

As far as terrorist fighters from China are concerned, the number of Uighurs fighting for various terrorist organizations in Syria was estimated at around 5,000 in May 2017 (Pickrell, 2017). These fighters pose serious threat not only to Syria, other Middle Eastern states or Europe. Beijing is concerned with a very likely scenario that they may come back to China and use their combat experience and military training against the Chinese state. From the People's Republic of China's perspective it seems more reasonable to engage in the conflict on the spot and attempt to eliminate these fighters in Syria and Iraq before they make their way home.

In case of the belt-and-road initiative, known previously as One Belt, One Road initiative, the Chinese motivation may not seem as obvious. The project is based on two routes: the land route and the maritime route. Yet it is clear and understandable that the land route will not be completed without stability and peace in the region. The policymakers in Beijing do understand that the Syrian conflict destabilizes not only Syria itself, but affects also all neighbouring countries with special emphasis on Turkey, Iraq, and Iran. The land route, namely the southern railroad route, is to pass through Iran and Turkey nearby Iraq and Syria and therefore the Chinese authorities will do their best to secure their future investments.

\section{YEMEN: TOWARDS ANOTHER BREAKUP?}

\section{Yemeni Warlords 2.0}

Some scholars claim that there is not just one Yemeni conflict, but rather three simultaneous conflicts. The first one is the Saudi-led campaign against the Houthis. The second conflict is, as Andrew Exum named it, the Iranian campaign whose main purpose is to destabilize the situation in Yemen and, at the same time, to distort freedom of commerce and trade in the Bab al-Mandeb strait. Finally, the third conflict is the U.S.-led military campaign against al-Qaeda of the Arabian Peninsula (Exum, 2017). It is also a personal conflict between Ali Abdullah Saleh, backed by Houthis, and Abdrabbuh Mansour Hadi, backed by the Saudi-led coalition. In this context, Elham Manea presents Yemen as a typical cunning state, which capitalizes on its "perceived weakness in order to render themselves unaccountable both to their citizens and to international institutions" (Manea, 2016: 164).

The Saudi intervention, initiated in 2015, has been widely condemned by the international community. Nonetheless, Riyadh can count on support of the United Arab 
Emirates, Bahrain, Jordan, Morocco, Sudan, Senegal, Pakistan, Turkey, Somalia, China, France, the United Kingdom, and the United States. Surprisingly, despite the enormous advantage, the Saudi-led forces cannot defeat Houthi fighters and their allies.

At the very beginning of 2017 many factors indicate that the Yemeni state is on a brink of yet another breakup. "South Yemen united with the more populous, tribal and rugged North Yemen only when the Soviet Union collapsed, leaving the south bereft of an external backer. After 27 years of forced but tempestuous marriage, its politicians have now latched onto the UAE, looking for separation again" (Atomised, 2017: 35). The external military intervention as well as actions undertaken by various terrorist organizations do not facilitate a peaceful resolution of the domestic conflict.

\section{Positions of the United States and the Russian Federation on the Yemeni Conflict}

Officially, under the Obama presidency, the United States did not support the Saudi-led military operations in Yemen, yet simultaneously Washington did not intend to criticize its key allies like Saudi Arabia or UAE and wreck good relationships in the region. At the same time the U.S. engaged in some ongoing operations against al-Qaeda of the Arabian Peninsula - AQAP. Its activities have been one of the biggest security concerns in Yemen since the beginning of the so-called transformation period. Charles Schmitz underlines the fact that "since the summer of 2012, al-Qaeda has launched a sustained campaign of assassinations against Yemeni security and military officers, killing high ranking officials with impunity" (Schmitz, 2014: 13).

Andrew Exum claims that "the Trump administration is trying to intensify its efforts to counter al-Qaeda in the Arabian Peninsula and the Houthi maritime threat because those efforts are in the interests of the United States" (Exum, 2017). Obviously, alQaeda's strongholds in Abyan, Shabwah, and Ma'rib governorates pose serious threat not only to the Yemeni national security, but also to international community.

The Russian attitude towards the Yemeni conflicts is much less clear than the American. Unlike the United States, the Russian Federation does not support any side of the war, although it still recognizes president Hadi as the only legitimate head of the Yemeni state. Simultaneously, however, Moscow has offered limited support to the Houthis especially since the beginning of the Saudi-led intervention in 2015. According to Mark N. Katz, it is a clear signal that "as it did during the Cold War, Moscow is now working with Yemeni forces that are in conflict with each other" (Katz, 2017). Tyler Nocita and Maher Farrukh are even taking one step further. In their opinion "Russia is increasing its engagement in Yemen as part of a regional re-entrenchment in the Middle East. It has sought to position itself as a mediator for the Yemeni civil war and seeks to secure naval basing on the Yemeni coast as part of a brokered political settlement" (Nocita, Farrukh, 2017). It may be one of the reasons why Russia, together with the United Nations, strongly condemned Saudi plans to take control over Hodeidah port. Both Russians and the UN claimed that such offensive would result in a humanitarian catastrophe. By the way, the Russian Federation provided medical aid to Yemen. This event was widely covered by Iranian media. 


\section{The Iranian Enigma}

Shahram Akbarzadeh and Dara Conduit underline the fact that "Saudi Arabia views the Houthi movement as an Iranian proxy and blamed Tehran for the unrest" (Akbarzadeh, Conduit, 2016: 10). This Saudi position on the roots of the ongoing Yemeni conflict is shared by other Arab states in general and members of the Gulf Cooperation Council except Oman in particular. Some scholars point out even that the Houthi rebellion is, as a matter of fact, another step towards the establishment of the so-called 'Shi' a Crescent'. Do such opinions on the Houthi-Iranian alliance derive from serious misinterpretations? On the one hand, according to Farideh Farhi, "although the media repeatedly identify the Houthis as Iranian backed, even those most alarmed by Iran's relationships to nonstate actors agree that the [Houthi] rebels are not yet part of Iran's transnational threat network: they are a local organization with local motives" (Farhi, 2017: 13). When the Houthis were approaching the Yemeni capital city - Sanaa in 2014, Iran reportedly tried to stop their offensive. Yet the Houthi commanders ignored Tehran's suggestions. What's more, Yemen was very low on the Iranian priority list. Iranians changed their mind only in 2016 when they began perceiving the conflict as another battleground of the rivalry with Saudi Arabia. The more the Arab Gulf states are engaged in the Yemeni conflicts, the less attention they can pay to the Iranian actions in the region. On the other hand, other scholars like Ibrahim Fraihat point out that "Iranian support for the Houthis against the Saudi airstrikes in March 2015 is not a secret and confirms the connection - though not the scale of the relationship - with the rebel movement" (Fraihat, 2016: 47).

The Iranian authorities criticize the Saudi-led coalition, especially Saudi Arabia, and accuse its members of war atrocities in Yemen. In July 2016 the Supreme Leader, Ali Khamenei, said: "The aggressor must stop its aggression and the Muslim world has to punish the aggressor that has invaded the Yemeni people for an unfounded reason" (Khamenei, 2016). President Rouhani also condemned the Saudi intervention in Yemen on a number of occasions. He said, inter alia, that "a government which is unaware of the issues in the region and the world, and is also quite a beginner, has decided to show some muscle for the first time" (Rouhani, 2016). Yet at the same time the Islamic Republic of Iran denies any closer affiliation with Houthis. Moreover, Teheran claims that it does not interfere in the Yemeni domestic affairs. Officially the Iranian support is limited to humanitarian assistance.

\section{The GCC Factor}

Tehran's stance is challenged by most of Arab countries in general and the GCC members in particular. In their opinion Iran is simply trying to enlarge its sphere of influence and for this reason is meddling in conflicts in Syria and Yemen. Yet at the same time they are trying to find a comprehensive settlement.

In the opinion of Gerald M. Feierstein, “after last year's Kuwait round of Yemeni negotiations ended in stalemate, the Saudi-led coalition determined that only a shift in the military balance would bring the Houthis and their allies, loyalists of former 
President Ali Abdullah Saleh, back to the negotiating table. A strategy was derived to push the Houthis off the Red Sea coast - the Yemeni terminus of the arms-smuggling route that begins in Iran - and seize the vital port of Hodeidah" (Feierstein, 2017). It is clear that this military campaign had not been successful and therefore Hadi's government, backed by Saudis, decided that Hodeidah could be transferred to a third party. If Houthis and their allies accepted such solution, then it would be easier to provide aid to millions of Yemenis. What's more, such a deal could be an important first step towards a comprehensive settlement of the conflict.

As Farid Senzai and Kamran Bokhari put it, "the Saudi position has become much weaker now that it has to deal with both the Zaydi and jihadist insurgencies, as well as a resurgent southern secessionist movement" (Senzai, Bokhari, 2017: 51-53). What had seemed to be an easy military campaign for Saudis in 2015, appeared to be a strategic trap in 2016. Lack of any significant military breakthrough as well as very limited if any chances for a constructive peace dialogue seriously undermined the regional position of Saudi Arabia. What's more, Riyadh perceives the ongoing Yemeni conflict primarily as another proxy war with Iran this way understating the role of local political cleavages and sectarian divisions. Moreover, the ongoing Saudi-led intervention costs a lot and has a significant impact on the economy of Saudi Arabia. According to some sources, in 2016 alone military operations in Yemen cost Saudi Arabia around $\$ 675$ million per month (Hussain, 2016).

All Gulf Cooperation Council members support president Hadi and the military intervention. The only exception is Oman which traditionally plays a role of a regional middleman or a peace broker. Recently the GCC member states supported president Hadi's opposition to the formation of a transitional political council in southern Yemen - a move which could result in a de facto separation of southern Yemen (GCC rejects, 2017). On the one hand, Hadi's opposition can be seen as an attempt to preserve territorial integrity of the Yemeni state. On the other hand, however, it could be also interpreted as a show of force and boldness.

All in all, Yemen is still threatened by the vision of a gradual and irreversible state disintegration. It is a scenario which is rooted deeply in Yemen's history, ethnic composition, and religious mosaic.

$$
* * *
$$

Although the global dimension can be observed and analysed in both selected conflicts, its seems to be much more noticeable and significant in case of the Syrian war especially due to the direct Russian engagement as well as the American response to it. At the beginning it was clear only as far as the UN Security Council meetings and resolutions were concerned. Later, especially when the Russian Federation sent its air force to Syria in 2015 in order to support the Assad regime, the situation changed to a great extent. The United States was forced to respond, although it had taken Americans almost two years before they undertook any real step in the Syrian case, namely in April 2017. Obviously, this solo effort could not change the situation on the ground, but it proved that President Trump's administration is ready for action and the Syrian leader will not be able to cross any more 'red lines' without painful consequences. 
What's more, it was a clear message for President Putin who might have thought that the Russian military presence in Syria was the best protection from any U.S. military strike against the Assad troops and their allies. At the same time, this message was received in Iran too.

A very limited institutionalization of international relations in the Middle East region seriously undermines opportunities for a peaceful conflict resolution in the region and therefore requires participation and engagement of non-regional actors especially global powers which can exert pressure on various regional actors. For instance, the Russian Federation can encourage al-Assad to participate in negotiations, while the United States has some leverage in case of the Arab states of the Persian Gulf and their allies in Syria.

In case of Yemen, the recent developments only prove that a lot depends on key regional actors especially Saudi Arabia, the UAE, and Iran. Besides, both the United States and, to some extent, the Russian Federation are engaged in the situation on the ground. This way the Yemeni war also gained its global dimension.

The Yemeni conflicts pose threat not only to Yemen's territorial integrity and welfare of its people, but also to the immediate neighbourhood. According to Karen E. Young, "while the immediate costs to the Yemeni people in famine, disease, and destruction have been clear, the future cost to Gulf neighbours, Saudi Arabia and the United Arab Emirates in particular, may be more than these states have estimated. As the expansive social science research on civil wars demonstrates, the cost of these conflicts tends to multiply, with reverberating effects in the domestic economy and in neighbouring states" (Young, 2017: 1).

\section{SHORT-TERM AND LONG-TERM SCENARIOS}

\section{The Case of Syria}

Marc Lynch claims that "Arab regimes have not even begun to deal with the underlying problems which drove the 2011 uprising, and most of those problems have gotten worse. The wars afflicting the region will not be resolved any time soon, and their impact will continue to be felt for many years to come. Few if any of America's traditional allies share its aspirations for the region, and conflict between them will likely continue" (Lynch, 2016: 241-242).

Will any positive change be possible in 2017 if president Assad stays in power? The answer is negative. Just a cursory analysis of events from the last six years shows that Assad's position is relatively strong. Charles Lister was right saying, in front of the United States House Committee on Foreign Affairs, that "in April 2017, the Assad regime found itself sat more comfortably in Damascus than at any point since the start of the crisis in the Spring of 2011. Its use of banned chemical weapons a few weeks ago is almost certainly a result of that confidence. However, if anyone believes that Bashar al-Assad is now the key to stabilizing Syria, they have learned nothing from the country's recent history. Assad cannot and will never be capable of putting Syria back together again" (Lister, 2017b). 
The Russian military presence as well as the American attack of April 2017 have changed the course of the Syrian conflict irreversibly. On the one hand, it seems unlikely that Russians will withdraw their forces without any comprehensive settlement or at least a certainty that Bashar al-Assad or any other Syrian leader friendly to Moscow will be able to preserve power. On the other hand, the American administration will be forced to conduct another attacks and increase its military presence either in Syria's neighbourhood or in Syria if the Assad regime commits any crimes against humanity. The United States reacted once and therefore it could lose all its credibility if it did not react to another attacks against civilians.

The re-election of the Iranian president Hassan Rouhani, which took place on 19 May 2017, may improve the situation in Syria as the Iranian authorities will enjoy bigger legitimacy as well as have incentive to undertake constructive steps within the peace process. Better relations with Western powers should result in more room for manoeuvre for both Iranian and Western diplomats.

However, for the time being, a major breakthrough in Syria is very unlikely. For this reason a few long-term scenarios seem to be possible, ranked below from the most to the least probable:

- the war will continue in some parts of Syria, but Bashar al-Assad will remain in charge with the help of the Russian, Chinese, and Iranian authorities;

- the conflict will be settled on the basis of a multilateral peace agreement signed in the framework of the Astana process without the involvement of Western powers;

- the conflict will be settled as a result of a multilateral peace agreement which will be concluded by all fighting groups, members of the Astana process - Russia, Iran, Turkey as well as China and Western powers like the United States and France.

As Obaida Fares claims, the failure of all negotiations "has been the result of the foreign and international intervention that started in early 2012. In all its forms, foreign intervention has undermined the will of the Syrian people and contributed to the prolonging of the conflict" (Fares, 2016: 158).

\section{The Yemeni Case}

At the beginning of 2017 all developments indicate that the Yemeni state has already become a failed state. From political point of view there seems to be no return to the status quo prior 2015. External interventions make it even more difficult to bring leaders of the main fighting groups to negotiations. Even members of the Saudi-led coalition may soon experience differences of opinions which might lead to serious tensions or even the end of joint actions. That's the case of Saudi Arabia and the UAE. Their leaders have their own ambitions and particular interests and therefore support different political fractions in Yemen.

Contrary to the Syrian conflict, Yemen draws much less attention of non-regional powers. While both the United States and the Russian Federation focus on the geopolitical and strategic importance of Syria, their authorities avoid any direct involvement in the Yemeni war, leaving it entirely in the hands of other actors such as Iran, Saudi Arabia, and the United Arab Emirates. Yet, like it happened in case of Syria in 
2016, Yemen may become an area of interest for the People's Republic of China. It's strategic location make it very important from the Chinese point of view as far as the belt-and-road initiative is concerned. Similarly to the Syrian case, Beijing may seek stability in the Arab Peninsula in order to secure maritime routes in the region. The Chinese authorities' excellent relations with both Riyadh and Tehran may appear crucial and very constructive.

At the very beginning of 2017 a few long-term scenarios, ranked below from the most to the least probable, seem to be possible:

- the conflict will continue without any major breakthroughs; all sides will control their spheres of influence, but the Yemeni state will still exist formally;

- the conflict will end up as a result of a multilateral peace agreement and Yemen's state structures will survive the conflict;

- Yemen will be formally divided into separate states on the basis of a negotiated settlement.

All in all, one can agree with Farid Senzai and Kamran Bokhari who predict that "Yemen will continue to simmer as a medium-intensity sectarian battleground; however, geography greatly insulates it from Iranian exploitation" (Senzai, Bokhari, 2017: 52). Beyond a shadow of a doubt, that's one of the main differences between the ongoing Syrian war and the Yemeni conflict.

\section{BIBLIOGRAPHY}

Acosta J., Smith-Spar L., Gaouette N. (2017), Trump has 'very, very good meeting with Lavrov, Kislyak at White House, CNN Politics, http://www.cnn.com/2017/05/10/politics/trump-lavrov-tillerson-meeting (10.05.2017).

Akbarzadeh S., Conduit D. (2016), Rouhani's First Two Years in Office, in: Iran in the World: President Rouhani's Foreign Policy, (eds.) S. Akbarzadeh, D. Conduit, Palgrave Macmillan, Basingstoke.

Alterman J. B. (2017), The Other Side of the World: China, the United States, and the Struggle for Middle East Security, Center for Strategic and International Studies, Washington D.C.

Atomised (2017), “The Economist”, 29.04.2017.

Baskan B. (2016), Turkey and Qatar in the Tangled Geopolitics in the Middle East, Palgrave Macmillan, New York.

Clarke M., Pantucci R. (2016), China is Supporting Syria's Regime. What Changed?, The National Interest, http://nationalinterest.org/feature/china-supporting-syrias-regime-whatchanged-17738 (13.05.2017).

Cooper T. (2015), Syrian Conflagration: The Civil War 2011-2013, Helion \& Company, Solihull.

Exum A. (2017), What's Really At Stake for America in Yemen's Conflict, "The Atlantic", 14.04.2017.

Fares O. (2016), The Arab Spring Comes to Syria: Internal Mobilization for Democratic Change, Militarization and Internationalization, in: Routledge Handbook of the Arab Spring: Rethinking Democratization, Routledge, Abingdon.

Farhi F. (2017), Iranian Power Projection Power and Goals, in: Deterring Iran After the Nuclear Deal, (eds.) K. H. Hicks, M. G. Dalton, Center for Strategic and International Studies, Rowman \& Littlefield, Lanham. 
Fayzullina K. (2016), The Arab Spring Through Russian 'Eyes', in: Routledge Handbook of the Arab Spring: Rethinking Democratization, Routledge, Abingdon.

Feierstein G. M. (2017), Yemen Could be the Key to Solving the Iran Problem, The Middle East Institute, http://www.mei.edu/content/yemen-could-be-key-solving-iran-problem (19.05.2017).

Fraihat I. (2016), Unfinished Revolutions: Yemen, Libya, and Tunisia After the Arab Spring, Yale University Press, New Haven.

Gause F. G. III (2014), The Foreign Policy of Saudi Arabia, in: The Foreign Policies of Middle East States, (eds.) R. Hinnebusch, A. Ehteshami, Lynne Rienner Publishers, Boulder.

GCC rejects formation of Yemen transitional council(2017), http://www.aljazeera.com/news/2017/05/ gcc-rejects-formation-yemen-transitional-council-170513141733873.html (19.05.2017).

Gibson B. R. (2017), Opportunities Lost: US Foreign Policy in the Middle East under Bush and Obama, 2000-2016, in: Reassessing Order and Disorder in the Middle East: Regional Imbalance or Disintegration?, (ed.) R. Mason, Rowman \& Littlefield, Lanham.

Glaser C. L., Kelanic R. A. (2016), Introduction, in: Crude Strategy: Rethinking the US Military Commitment to Defend Persian Gulf Oil, (eds.) C. L. Glaser, R. A. Kelanic, Georgetown University Press, Washington D.C.

Hinnebusch R. (2014), Foreign Policy in the Middle East, in: The Foreign Policies of Middle East States, (eds.) R. Hinnebusch, A. Ehteshami, Lynne Rienner Publishers, Boulder.

Hussein M. (2016), Saudi intervention in Yemen and its impact on Saudi's economy, Foreign Policy News, http://foreignpolicynews.org/2016/12/11/saudi-intervention-yemen-impact-saudiseconomy/ (22.05.2017).

Katz M. N. (2017), Russia Maneuvers between Opposing Forces in Yemen, The Arab Gulf States Institute in Washington, http://www.agsiw.org/russia-maneuvers-opposing-forces-yemen/ (22.05.2017).

Katzman K. (2017), Iran's Foreign and Defense Policies, CRS Report R44017, Congressional Research Service, Washington D.C.

Khlebnikov A. (2017), Russia Needs Astana to Succeed, The Middle East Institute, http://www.mei. edu/content/article/russia-seeks-compromise-syria-astana-talks-continue (10.05.2017).

Khamenei A. (2016), Ayatollah Khamenei: US Seeks to Eclipse Palestine Issue, The Office of the Supreme Leader, http://www.leader.ir/en/content/15955/The-Leader-meeting-Muslim-ambassadors-and-officials-on-Eid-al-Fitr (19.05.2017).

Lister C. (2017a), Lavrov to Visit Washington Seeking U.S. Support on Syria Plan, The Middle East Institute, http://www.mei.edu/content/article/russia-seeks-us-support-syria-plan-mondaybriefing (10.05.2017).

Lister C. (2017b), Testimony: Syria After the Missile Strikes - Policy Options, The Middle East Institute, http://www.mei.edu/content/article/testimony-syria-after-missile-strikes-policy-options (12.05.2017).

Manea E. (2014), Yemen's Arab Spring: Outsmarting the Cunning State?, in: Routledge Handbook of the Arab Spring: Rethinking Democratization, Routledge, Abingdon.

Mason R. (2017), Turkish Regional Policy in the Modern Era: From "Zero Problems" to Few Options, in: Reassessing Order and Disorder in the Middle East: Regional Imbalance or Disintegration?, (ed.) R. Mason, Rowman \& Littlefield, Lanham.

Nocita T., Farrukh M. (2017), Yemen Crisis Situation Report, Critical Threats, https://www.criticalthreats.org/briefs/yemen-situation-report/2017-yemen-crisis-situation-report-april-28 (22.05.2017). 
Phillips C. (2016), The Battle for Syria: International Rivalry in the New Middle East, Yale University Press, New Haven.

Pickrell R. (2017), Why are 5,000 Chinese fighting in Syria 's Civil War?, The National Interest, http:// nationalinterest.org/blog/the-buzz/why-are-5000-chinese-fighting-syrias-civil-war-20562 (18.05.2017).

Rafizadeh M. (2016), Iran's Forces Outnumber Assad's in Syria, Gatestone Institute, https://www. gatestoneinstitute.org/9406/iran-soldiers-syria (22.05.2017).

Robins P. (2014), The Foreign Policy of Turkey, in: The Foreign Policies of Middle East States, (eds.) R. Hinnebusch, A. Ehteshami, Lynne Rienner Publishers, Boulder.

Rouhani H. (2016), The Bombing of Innocent and Defenseless People of Yemen is a Strategic Mistake, Official Website of the President of the Islamic Republic of Iran, http://www.president. ir/en/search (19.05.2017).

Schmitz C. (2014), Yemen's National Dialogue, MEI Policy Paper - 1, http://www.mei.edu/sites/ default/files/publications/Charles\%20Schmitz\%20Policy\%20Paper.pdf (24.05.2017).

Senzai F., Bokhari K. (2017), Geosectarianism and Translocal Politics, in: Reassessing Order and Disorder in the Middle East: Regional Imbalance or Disintegration?, (ed.) R. Mason, Rowman \& Littlefield, Lanham.

Sharafadin B. (2016), Death toll among Iran's forces in Syrian war passes 1000, Reuters, http:// www.reuters.com/article/us-mideast-crisis-syria-iran-idUSKBN13H16J (21.05.2017).

Tillerson R. (2017), Chemical Weapons Attack in Syria, the United States Department of State, Press Statement, https://www.state.gov/secretary/remarks/2017/04/269460.htm (10.05.2017).

Walker J. W. (2012), Reclaiming Turkey's Imperial Past, in: Turkey and Its Neighbors: Foreign Relations in Transition, (ed.) R. H. Linden, Lynne Rienner Publishers, Boulder.

Young K. E. (2017), War at Any Price: Domestic and Regional Economic Consequences of Yemen's Civil War, The Arab Gulf States Institute, Washington D.C.

\begin{abstract}
The main aim of the article is to analyse in detail roles played by various regional and nonregional state actors in two of the ongoing Middle Eastern conflicts, namely in Syria and in Yemen, in the period between March 2015 and May 2017. The year 2015 was very significant. That year the Russian military intervention in Syria began, the conflict in Yemen broke out and was internationalized simultaneously.

This state-oriented study has two levels of analysis, namely regional and global. Although the global dimension can be observed and analysed in both selected conflicts, its seems to be much more noticeable and significant in case of the Syrian war especially due to the direct Russian engagement as well as the American response to it.

A very limited institutionalization of international relations in the Middle East region seriously undermines opportunities for a peaceful conflict resolution in the region and therefore requires participation and engagement of non-regional actors especially of global powers which can exert either direct or indirect pressure on various regional actors.

As far as sources are concerned, the study is based on selected documents, monographs, academic articles, reports, and analyses.
\end{abstract}

Keywords: Syria, Yemen, the Middle East, conflict, regional level, global level 


\section{KONFLIKTY ZBROJNE W SYRII I JEMENIE: ROZWÓJ, KONSEKWENCJE I MOŻLIWE SCENARIUSZE}

\section{STRESZCZENIE}

Głównym celem niniejszego artykułu jest szczegółowa analiza ról odgrywanych przez wybranych aktorów państwowych w dwóch trwających konfliktach bliskowschodnich - w Syrii oraz Jemenie. Ramy czasowe obejmują okres od marca 2015 do maja 2017 roku. Rok 2015 był rokiem szczególnym, w trakcie którego rozpoczęła się rosyjska interwencja zbrojna w Syrii, a konflikt w Jemenie został umiędzynarodowiony. Analiza zaangażowania aktorów państwowych przeprowadzona została na dwóch poziomach: regionalnym oraz globalnym. Chociaż wymiar globalny można zaobserwować w obu przypadkach, to jednak wydaje się on być bardziej zauważalny w przypadku Syrii, ze względu na większe zaangażowanie ze strony mocarstw (Stany Zjednoczone, Federacja Rosyjska). Największe ograniczenie wszelkich inicjatyw pokojowych w regionie Bliskiego Wschodu stanowi bardzo niski poziom instytucjonalizacji stosunków międzynarodowych. Z tego powodu pokojowe rozwiązywanie konfliktów w regionie wymaga zaangażowania ze strony aktorów spoza Bliskiego Wschodu, którzy w sposób bezpośredni lub pośredni mogą wywierać presję na aktorów regionalnych. Podstawę źródłową analizy stanowią wybrane dokumenty, monografie, artykuły naukowe, raporty oraz ekspertyzy.

Słowa kluczowe: Syria, Jemen, Bliski Wschód, konflikt, poziom regionalny, poziom globalny 